\title{
The Influence of Security and Technical Quality on Intention to Use Big Blue Button for E-learning
}

\author{
Noor Muqaibal ${ }^{\# 1}$ \\ \# College of Commerce and Business Administration
}

\begin{abstract}
Purpose: This research work aimed to investigate the Influence of Security, and Technical Quality on Intention to Use Big Blue Button for E-learning (IUBBEL).

Methodology: A descriptive and quantitative research methodology was conducted to gather and analysis the study's variables (Security, Technical Quality and IUBBEL) and hypotheses.

Sample: 79 students.

Data Collection Tool: The researcher used the questionnaire as tool for data collection.

Findings: there is a significant effect of security on the intention to use BBB for E-learning, whereas Technical Quality has no effect.
\end{abstract}

Keywords - Security, technical quality, Big Blue Button, E-Learning

\section{INTRODUCTION}

We can say that Information and Communication Technologies (ICT) have penetrated all sectors of society. In this sense, we cannot talk about these technologies without referring to the context of their use and production. However, this context is very different in each field of application, and the problematic in the field of education, because it falls within the competence of all the members of a society, is very complex. Learning, because of what we can call its strategic situation, simultaneously concerns the fields of communication and learning[1], and yet the interests of the actors involved are very different and frequently oppose or contradict each other [2], [3]. The merge of ICT and learning provided a new concept known as E-learning which defined according to [4] as a systematic use of multimedia technologies to empower the learner, improve learning, connect the learner with resources allowing him to meet his needs and integrate learning, performance, individual and organizational goals [5], [6]. In the studies of [7], E-learning is any learning activity supported by ICT.

The learner still faces some factors which may had significant influence on their intention to adopt the elearning systems. In this study, the researcher will investigate the influence of the security and the technical quality of the e-learning system [8]. The Security factor was considered as the safety level of the content on the courses online and the level of authentication when using the e-learning system[1], [9], whereas the technical quality describes the quality of hardware (Computers, Servers, Network, etc.) part used in e-learning system among the online e-learning platform [10], [11][12]. This research work will investigate the influence of these factors on the intention of students to use the BBB for e-learning.

Hence, this study trying to investigate the availability levels of Security, technical quality, and Intention to use new technology in education sector i.e. using the conferencing platform Big Blue Button in e-learning from students' perspective. Also, the effect of security and technical quality on the Intention to use the conferencing platform Big Blue Button in e-learning from students' perspective.

\section{Literature REVIEW}

According to the study of Al-Jarf (2019) these studies addressed the issue of traditional and distance education together. Students of the College of Languages and Translation at King Saud University in Saudi Arabia participated in this study.

It was found through the results of this study that applied students who practiced traditional learning in the English subject were less able to comprehend reading and writing in this subject. On the other hand, the study proved that the group that practiced distance learning in English subject had better abilities than the first group. 
It was found that distance learning helped students in comprehension more through the use of simulation technology in education.

Referring to the study of Alanazi \& Alshaalan (2020) the study touched on the importance of e-learning and the challenges it faces, the most important of which is the infrastructure for adopting e-learning. Through a survey conducted by researchers, the necessity of adopting e-learning was reached due to its ability to generate information by relying on digital persuasion methods. Modern. The study also proved that the great role of distance learning is hostage to the information technology infrastructure that is adopted, especially the Internet [13].

Through this study, the researchers recommended the need to adopt national plans to evaluate e-learning requirements, and new controls should be implemented to push them further. According to the study of Wang et al. (2020), E-learning currently occupies a high position in universities and academic institutes and is given priority by the departments in these institutions Educational. The development we are witnessing today in information technology, communications, wireless networks, and multimedia is driving in The trend of adopting e-learning in education. Where learners are provided with learning and knowledge using technology and in a continuous manner regardless of place and time by providing educational materials organized in an electronic form that the learner can review and learn from, either side Combined with traditional learning, or distance learning [14].

To study the reality of e-learning in Jordanian universities, and focus on the most important issues and challenges that he faces, and ways to enhance it Its uses are for the sake of developing educational methods and pedagogy, in addition to that it is considered one of the most important factors to mitigate the burden on resources. Humanity and university infrastructure. The research tries to remove the ambiguity around the concept of e-learning as a tool for cross-student development Self-education and the enhancement of his critical thinking so that this is reflected in his practice and the generation of his ability to interact with his surroundings and acquire knowledge and the skill and mastery of techniques and tools while on the desk and beyond through life-long learning. Work concludes The need to develop a national strategy aimed at developing the educational system in Jordanian universities to enhance its regional and global competitiveness and accreditation E-learning is a fundamental pillar of the strategy and designing a program to build the capacity of the faculty in information technology. And pedagogy and pedagogy being the basic components of e-learning.

Al-Hazeem H, G (2018) Electronic solutions in the educational process, E-learning and blended theory and practice by an open source Moodle version [15].

Mankind, in all its spectrums and ethnic cultural paths, and its different material and economic levels, has been concerned with the issue of learning and science when It has an impact on the development of the individual and his capabilities in many areas. Therefore, the educational process was a concern of all nations and peoples. And achieving the desired goals of education is essential for specialists In the educational field. Here, one of the purposes of this study is to clarify the technical and dependent methods on information technology and its applications such as an open source system

An example is Moodle to achieve this goal, while showing distance learning as a comprehensive concept under which electronic education falls in both its simultaneous and non-simultaneous parts. Concurrent with clarifying the role of the Internet as an applied e-learning environment for this type of learning.

Study boutoura, (2019) The effect of e-learning on achieving the comprehensive quality in higher education institutions.

The study aimed at clarifying the importance of e-learning in achieving quality in higher education institutions in all disciplines to achieve quality in its knowledge outputs of education and scientific research. In a world where knowledge and technology is its main currency and e-learning model, Integrated and comprehensive through mechanisms and practices to ensure the achievement of the overall quality in education, and then exploit all the capacities available in these institutions and harnessing them to serve and develop the society and its age. 


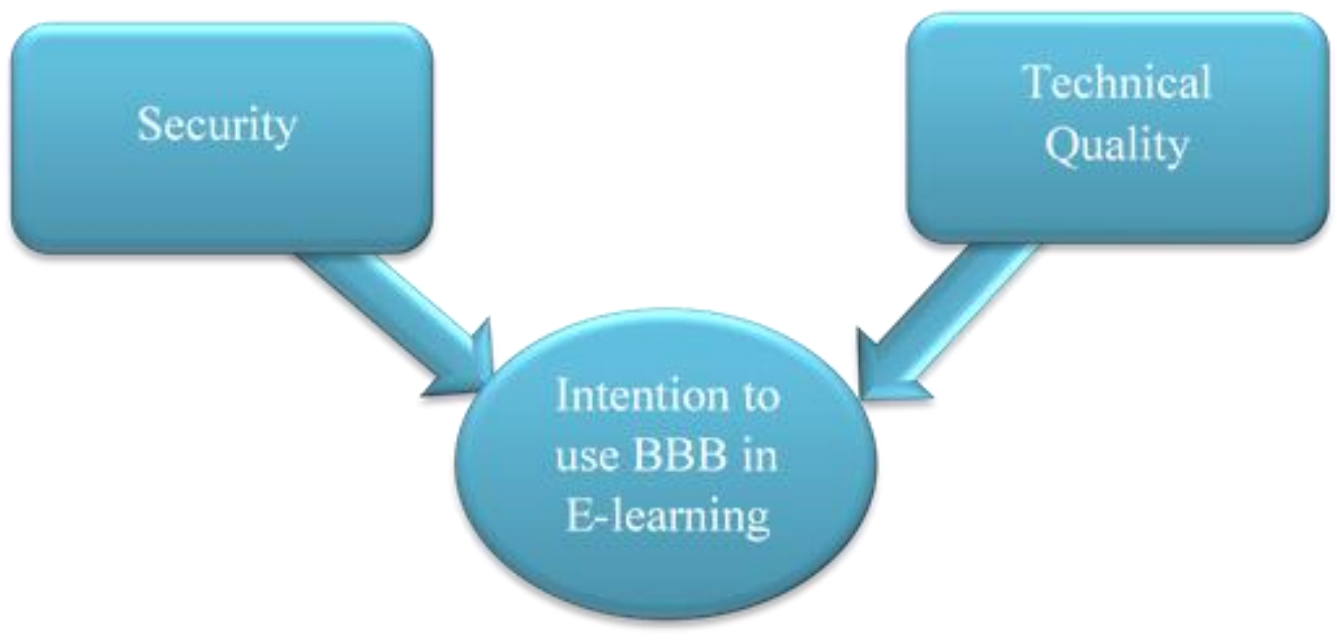

Thereby the current study proposed the following hypotheses:

- H1: Security have a positive impact on Intention to use the conferencing platform Big Blue Button in e-learning from students' perspective.

- $\quad$ H2: Technical Quality have a positive impact on Intention to use the conferencing platform Big Blue Button in e-learning from students' perspective.

\section{III.METHODS}

The selected sample in this research work consists of 79 students. The researcher used the questionnaire instrument to gather data from the selected sample of students. The researcher analyzed the gathered data using the descriptive, correlation and regression analyses with the help of the SPSS software[16], [17].

\section{IV.ANALYSIS}

Reliability: The researcher used the Cronbach's alpha value to check the reliability of the study variables[18]:

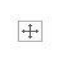

Table(1): Reliability Statistics

\begin{tabular}{|c|c|c|}
\hline Scale & Cronbach's Alpha & N of Items \\
\hline Security & .601 & 3 \\
\hline technical quality & .606 & 3 \\
\hline Intention to use Big Blue Button for e-learning & .894 & 2 \\
\hline
\end{tabular}

From the reliability statistics presented in the above table, the measured Cronbach's Alpha for Security is 0.601 and for Technical Quality, it reached 0.606 whereas the Cronbach's Alpha of Intention to use BBB for Elearning is 0.894 [19]. 


\section{A. Participants information}

\begin{tabular}{|c|c|}
\hline \multicolumn{2}{|c|}{ Table (2) Participants profile } \\
\hline Male & 14 \\
\hline Female & 65 \\
\hline Total & 79 \\
\hline Diploma of high school & 24 \\
\hline Diploma & 12 \\
\hline Bachelor & 42 \\
\hline Master's degree or PH.D & 1 \\
\hline Total & 79 \\
\hline $\mathbf{1 8}$ to less than 28 & 66 \\
\hline $\mathbf{2 8}$ to less than 38 & 9 \\
\hline $\mathbf{3 8}$ to less than $\mathbf{4 8}$ & 1 \\
\hline $\mathbf{4 8}$ to less than 58 & 3 \\
\hline Total & 79 \\
\hline
\end{tabular}

\section{B. Descriptive Test}

Table (3): variables Descriptive Statistics

\begin{tabular}{|c|c|c|c|}
\hline & Type & Mean & Std. Deviation \\
\hline Security & Independent & 2.996 & 1.0021 \\
\hline Technical Quality & Independent & 3.629 & .6814 \\
\hline Intention to Use BBB & Dependent & 3.348 & 1.1075 \\
\hline
\end{tabular}

As shown above, Security reached 2.996 of mean value and 1 of Std. Deviation, Technical Quality reached 3.629 of Mean value and 0.68 of Std. Deviation whereas Intention to Use BBB reached 3.348 of Mean value and 1.1 of Std. Deviation [20], [21].

\section{HYPotheses TEST}

Both Security and Technical Quality putt together and tested via Multiple Regression[22]: 
Table 4 Model Summary

\begin{tabular}{|c|c|c|c|c|}
\hline M odel & $R$ & R Square & $\begin{array}{c}\text { Adjusted } R \\
\text { Square }\end{array}$ & $\begin{array}{c}\text { Std. Error of } \\
\text { the Estimate }\end{array}$ \\
\hline 1 & $.474 a$ & .224 & .204 & .9882 \\
\hline
\end{tabular}

a. Predictors: (Constant), Security, TechnicalQuality

Table 5 ANOVA

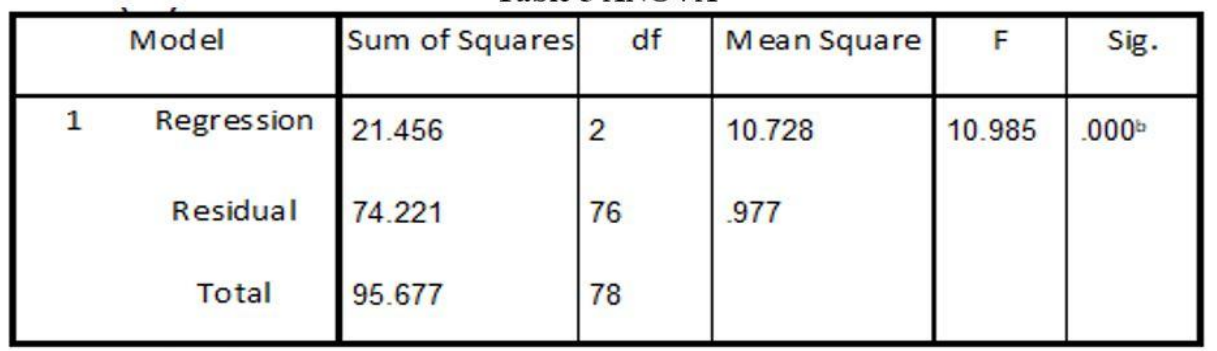

a. Dependent Variable: Use BBB

b. Predictors: (Constant), Security, Technical Quality

Table 6 Coefficients

\begin{tabular}{|c|c|c|c|c|c|c|}
\hline \multicolumn{2}{|r|}{ Model } & \multicolumn{2}{|c|}{$\begin{array}{l}\text { Unstandardized } \\
\text { Coefficients }\end{array}$} & \multirow{2}{*}{$\begin{array}{c}\text { Standardized } \\
\text { Coefficients }\end{array}$} & \multirow[t]{2}{*}{$\mathrm{t}$} & \multirow[t]{2}{*}{ Sig. } \\
\hline & & $\mathrm{B}$ & Std. Error & & & \\
\hline \multirow[t]{3}{*}{1} & (Constant) & 2.476 & .716 & & 3.460 & .001 \\
\hline & Technical Quality & -.173 & .165 & -.107 & -1.053 & 216 \\
\hline & Security & .501 & .112 & .453 & 4.475 & .000 \\
\hline
\end{tabular}

a. Dependent Variable: Intention to Use BBB

As it shown from tables $(4,5$ and 6$)\left(\mathrm{R}^{2}=0.224\right)$, this means that both Security and Technical Quality had $(22.4 \%)$ of the total variation in the Intention to Use BBB F test $(\mathrm{F}=10.985)$ and the $\mathrm{P}$-value is 0.000 which is significant $(\mathrm{P}<0.0)$. It is inferred from these values that only Security $(\mathrm{P}<0.05)$ affect the Intention to Use BBB for E-learning [23], [24], therefore we will accept the first hypothesis. Meanwhile, Technical Quality significantly $(\mathrm{P}=0.216>0.05)$ thereby we will reject the second hypothesis.

\section{VI.Discussion}

The main aim of this research work was to find out the extend effect of both security and Technical quality on the intention to adopt BBB by students in University. It is concluded from the study that the security level has a significant effect on the intention to adopt e-learning using BBB, this can be due to the lack of trust towards the circulation of personal information through Internet so in this case the security is a main need for adopting the BBB among students of DU. It is concluded also that the Technical Quality has no influence on the adoption of $\mathrm{BBB}$, this can be justified by that students have no problem when using new technology such as smart phone or other technology tools.

The study's findings were agreeing with the study of Al-Khasawneh (2012) in terms of Security, this can be due to the difference between background of the populations of the two studies. 
The study's findings were agreeing with the study of Al-Hazeem (2013) in terms of Technical Quality which may be due to the spread of technologies around the world where students found no problem in using technologies in learning.

The $\mathrm{H} 1$ proposed hypothesis was accepted whereas the proposed H2 hypothesis was rejected. In this study, only Security can be considered as main factor influencing the intention to use BBB for e-learning in University.

- After the discussion of the obtained results, the researcher puts the below recommendations:

- University management should follow the level of security in its adopted BBB system,

- Students should be aware that such system based on a secured information system,

- Students do not view that technical quality is a factor of BBB adoption in e-learning, so they should be aware that the higher the technical quality, the higher the quality of e-learning, University management should enhance its BBB system by using the newest technology tools.

\section{REFERENCES}

[1] H. Hassan, "The effect of the cloud learning management system on developing the level of technological acceptance among instructional technology students," Journal of research in education, 2020.

[2] M. N. Alraja, "User Acceptance of Information Technology: A Field Study of an E-Mail System Adoption from the Individual Students' Perspective," Mediterranean Journal of Social Sciences, vol. 6, no. 6 s1, pp. 19-25, Nov. 2015, doi: 10.5901/mjss.2015.v6n6s1p19.

[3] M. A. Uddin, F. Ahmar, and M. N. Alraja, "E-Examinations for Management Students in Oman," International Journal of Applied Business and Economic Research, vol. 14, no. 1, pp. 87-95, May 2016, Accessed: Nov. 27, 2020. [Online]. Available: https://papers.ssrn.com/abstract=2959732.

[4] E. Fianu, C. Blewett, G. O. A. Ampong, and K. S. Ofori, "Factors affecting MOOC usage by students in selected Ghanaian universities," Education Sciences, vol. 8, no. 2, Jun. 2018, doi: 10.3390/educsci8020070.

[5] M. N. Alraja, "The effect of social influence and facilitating conditions on e-government acceptance from the individual employees' perspective | Efekt Wpływu Społecznego Oraz Warunków Ułatwiających Akceptację E-Administracji Z Punktu Widzenia Indywidualnych Pracowników,” Polish Journal of Management Studies, vol. 14, no. 2, 2016, doi: 10.17512/pjms.2016.14.2.02.

[6] M. A. Hussein, H. M. S. Ahmed, and M. N. Alraja, "The adoption of information and communication technology by small and medium enterprises in Oman: Case of Dhofar region," Journal of Business and Retail Management Research (JBRMR), vol. 11, no. 3, pp. 64-71, 2017, Accessed: May 17, 2019. [Online]. Available: www.jbrmr.com.

[7] K. Vasanth and J. Sbert, “Creating solutions for health through technology innovation,” Dallas, 2014. Accessed: Jan. $23,2019$. [Online]. Available: http://www.ti.com/lit/wp/sszy006/sszy006.pdf.

[8] J. Hashim, "Learning barriers in adopting ICT among selected working women in Malaysia," Gender in Management: An International Journal, vol. 23, no. 5, pp. 317-336, Jul. 2008, doi: 10.1108/17542410810887356.

[9] F. M. Alkhaldi, S. M. Hammami, S. Kasem, A. Rashed, and M. N. Alraja, "Enterprise System as Business Intelligence and Knowledge Capabilities for Enhancing Applications and Practices of IT Governance," International Journal of Organizational and Collective Intelligence (IJOCI), vol. 7, no. 2, pp. 63-77, 2017, doi: 10.4018/IJOCI.2017040105.

[10] S. N. Samsudeen and R. Mohamed, "University students' intention to use e-learning systems: A study of higher educational institutions in Sri Lanka," Interactive Technology and Smart Education, vol. 16, no. 3, pp. 219-238, Sep. 2019, doi: 10.1108/ITSE11-2018-0092.

[11] M. N. Alraja, S. Hammami, B. Chikhi, and S. Fekir, "The Influence of Effort and Performance Expectancy on Employees to Adopt E-government: Evidence from Oman," International Review of Management and Marketing, vol. 6, no. 4, pp. 930-934, Oct. 2016, Accessed: Nov. 27, 2020. [Online]. Available: http:www.econjournals.com.

[12] M. N. Alraja, M. A. Hussein, and H. M. S. Ahmed, "What affects digitalization process in developing economies? an evidence from SMEs sector in Oman," Bulletin of Electrical Engineering and Informatics, vol. 10, no. 1, Feb. 2021, doi: 10.11591/EEI.V10I1.2033.

[13] Alanazi and Z. M. Alshaalan, "Views of faculty members on the use of e-learning in Saudi medical and health colleges during COVID-19 pandemic," Journal of Nature and Science of Medicine, vol. 3, no. 4, p. 308, 2020, doi: 10.4103/JNSM.JNSM_82_20.

[14] L. Y. K. Wang, S. L. Lew, and S. H. Lau, "An empirical study of students' intention to use cloud e-learning in higher education," International Journal of Emerging Technologies in Learning, vol. 15, no. 9, pp. 19-38, 2020, doi: 10.3991/ijet.v15i09.11867. 


\section{DOI: $10.51386 / 25815946 /$ ijsms-v3i6p107}

[15] N. Popovic, T. Popovic, I. R. Dragovic, and O. Cmiljanic, “A Moodle-based blended learning solution for physiology education in Montenegro: A case study,” Advances in Physiology Education, vol. 42, no. 1, pp. 111-117, 2018, doi: 10.1152/ADVAN.00155.2017.

[16] M. N. Alraja, S. F. Khan, B. Khashab, and R. Aldaas, "Does Facebook Commerce Enhance SMEs Performance? A Structural Equation Analysis of Omani SMEs,” SAGE Open, vol. 10, no. 1, p. 215824401990018, Jan. 2020, doi: 10.1177/2158244019900186.

[17] L. Sulaiman, "Information Security: Cost and Individuals' Habit,” International Journal of Science and Management Studies (IJSMS), vol. 1, no. 3, pp. 12-15, 2018, Accessed: Dec. 26, 2020. [Online]. Available: www.ijsmsjournal.org.

[18] M. N. Alraja, M. M. J. Farooque, and B. Khashab, "The Effect of Security, Privacy, Familiarity and Trust on Users' Attitudes Towards the Use of IoT-based Healthcare: The Mediation Role of RiskPerception," IEEE Access, vol. 7, pp. 1-1, 2019, doi: 10.1109/access.2019.2904006.

[19] N. M. M. A. Malkawi, M. N. Alraja, and T. Alkhayer, "Information Systems Auditing Applied Study at Banks Listed in the Damascus Stock Exchange Syria," European Journal of Economics, Finance \& Administrative Sciences, no. 21, p. 119, 2010, Accessed: May 17, 2019. [Online]. Available: http://connection.ebscohost.com/c/articles/52428507/information-systems-auditingapplied-study-banks-listed-damascus-stock-exchange-syria.

[20] M. N. Alraja and N. R. Alomian, "The Effect of General Controls of Information System Auditing in the Performance of Information Systems :Field Study," INTERDISCIPLINARY JOURNAL OF CONTEMPORARY RESEARCH IN BUSINESS, vol. 5, no. 3, pp. 356370, 2013, Accessed: May 17, 2019. [Online]. Available: https://www.researchgate.net/publication/281465359.

[21] M. N. Alraja and N. R. Alomian, "THE EFFECT OF INFORMATION TECHNOLOGY IN EMPOWERMENT PUBLIC SECTOR EMPLOYEES: A FIELD STUDY," INTERDISCIPLINARY JOURNAL OF CONTEMPORARY RESEARCH IN BUSINESS, vol. 5, no. 1, pp. 805-815, 2013, Accessed: May 17, 2019. [Online]. Available: https://journal-archieves32.webs.com/805-815.pdf.

[22] S. Al Harizi and S. O. Al Marhoon, "Factors Affecting the Adoption of E-Commerce: An Evidence from Developing Country," International Journal of Science and Management Studies (IJSMS), vol. 2, no. 3, pp. 86-90, 2019, Accessed: Jun. 24, 2019. [Online]. Available: www.ijsmsjournal.org.

[23] M. N. Alraja and B. Chikhi, "Perceived Factors affecting Customers Attitudes toward Electronic Shopping: an Empirical Study," International Journal of Economic Research, vol. 12, no. 3, pp. 815-823, 2015, Accessed: May 17, 2019. [Online]. Available: http://serialsjournals.com/abstract/51627_17.pdf.

[24] M. N. Alraja and N. M. M. Malkawi, "E-Business adoption in banking sector: Empirical study," Indian Journal of Science and Technology, vol. 8, no. 27, 2015, doi: 10.17485/ijst/2015/v8i27/70739. 